\title{
Deuses e marionetes: Kathakali, teatro dança clássico da Índia e seus delicados diálogos
}

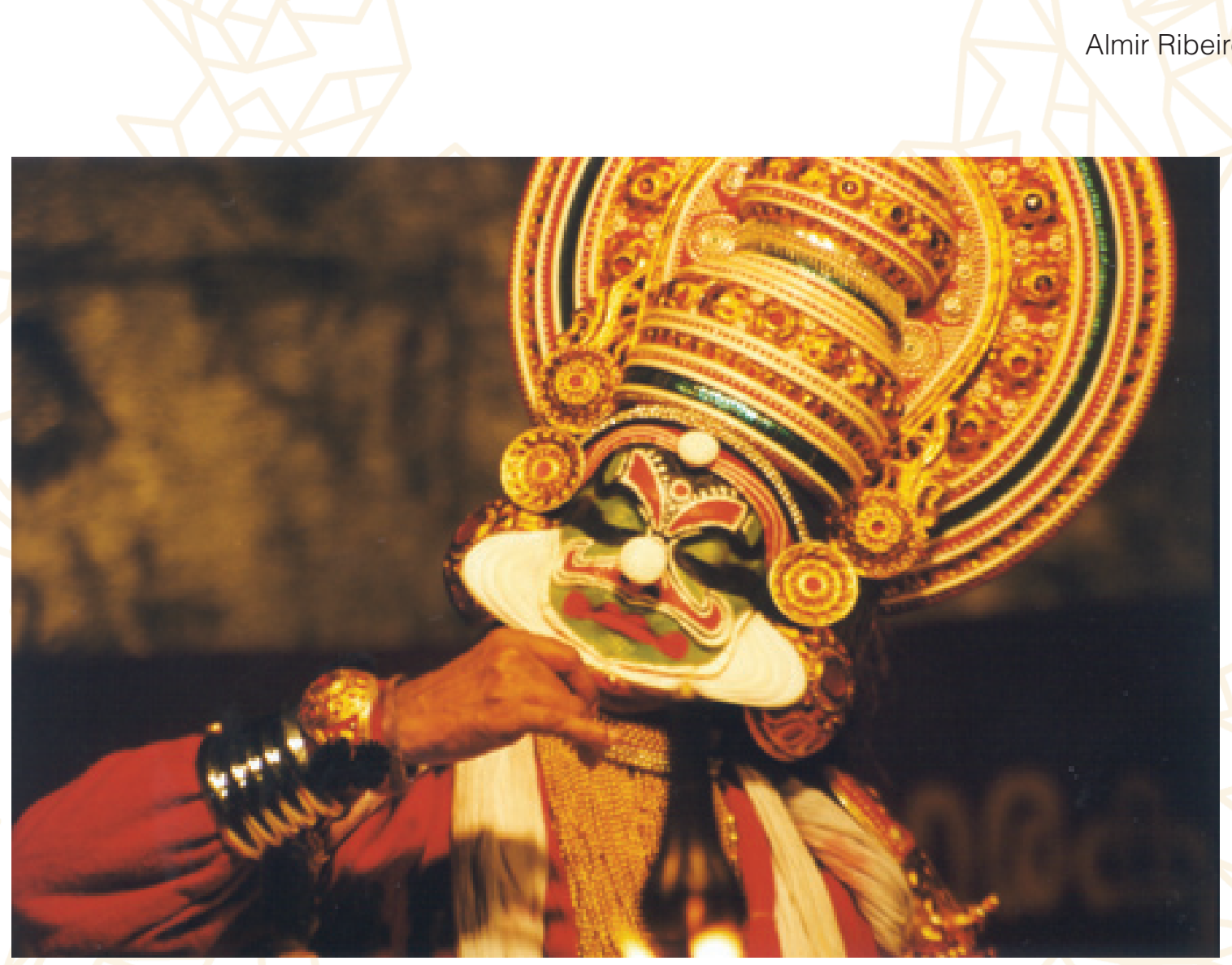

\section{Resumo}

O Kathakali é um estilo masculino de Teatro-dança clássico originário na antiga região do Malabar, no sudoeste da Índia. Sua forma final supõe-se ter sido atingida ao final do século XVII, mas suas raízes culturais são encontradas em rituais dramatizados cujas primeiras documentações remontam a quase dois mil anos. O Kathakali é o produto final de uma longa elaboração cultural particular e, principalmente, irrepetível. No entanto, sua estética, linguagem cênica e tradição atoral, com seu treinamento e práxis, ainda hoje inspiram reflexões importantes sobre a arte teatral. Longe de ensejar uma idealização exótica e estéril, esta modesta introdução almeja apenas apontar algumas dessas reflexões à que o Kathakali convida: participante ativo, dialogante e fricativo do que chamamos de Contemporaneidade.

Palavras-chave: Teatro; Kathakali; Índia; Interculturalismo;

1 Almir Ribeiro é diretor teatral, pedagogo, Mestre em Artes Visuais pela UFRJ e doutorando em Artes Cênicas pela USP com o projeto Edward Gordon Craig: a Supermarionete e a pedagogia da Morte do ator. É autor do livro Kathakali: uma introdução ao Teatro e ao sagrado da Índia. 


\begin{abstract}
Kathakali is a masculine style of Indian classical dance-theatre originated in the ancient region of Malabar, southwestern of India. Its final form is supposed to have been attained at the end of the seventeenth century, but its roots are found in cultural rituals dramatized whose first documentation dating back to almost two thousand years. The Kathakali is the final output of a singular, and most especially, unrepeatable long cultural elaboration. However, its aesthetic, scenic language and acting tradition - with their praxis and arduous training - even today inspire important reflections on the art of theatre. Far from trying to give rise to any kind of exotic and sterile idealization, this modest introduction aims just point out some of these reflections that Kathakali calls on: an active, dialoguing and fricative player of what we use to call Contemporary.
\end{abstract}

Keywords: Theatre; Kathakali; India; Interculturalism.

O Teatro deve suscitar em nós a nostalgia daquilo que não pertence a este mundo (CRAIG in SAVARESE, 1980, p. 389).

O palco está parcialmente oculto por uma cortina suspensa por dois ajudantes. Sabe-se que o ator está atrás da cortina, pois se pode ver o alto de sua enorme coroa que se move lentamente. Os gritos do personagem e o barulho dos guizos atados em suas pernas somam-se ao estrondo dos tambores que tocam em ritmo vigoroso. Subitamente, as mãos do ator surgem agarrando a parte de cima da cortina. Ele a balança para um lado e para o outro, sem, no entanto, mostrar sua figura. Suas mãos liberam a cortina e ele volta a dançar, oculto ainda da audiência ansiosa. Novos gritos, e os tambores retomam sua força. Outra vez ele segura a cortina e a agita. De repente, com um gesto inesperado e brusco revela sua face amedrontadora. Em sua maquiagem, o vermelho predomina e seus olhos contornados de negro, parecem querer saltar das órbitas enquanto fitam o público. De sua boca emergem enormes e grotescos caninos. O aspecto demoníaco é do vilão Dushássana, que no épico Mahabharata é inimigo dos heróis Pandavas. Primos do deus Krishna, os cinco irmãos Pandavas, por um capricho do destino, foram destinados a desposarem uma única e mesma esposa, Dráupadi. Um dos irmãos, Bhima, famoso por sua força sobre humana, uma espécie de Hércules hindu, surge em cena para enfrentar o vilão e uma luta terrível se inicia. Por fim, Bhima golpeia mortalmente Dushássana. Com o vilão caído, Bhima abre sua barriga, bebe seu sangue, retira suas entranhas e dança com elas entre seus dentes. Bhima chama sua esposa, Dráupadi, a quem Dushássana havia insultado ao arrastá-la pelos cabelos. Bhima pede que ela se aproxime do cadáver e então lava o cabelo da esposa, como desagravo, com o sangue do vilão morto. Dráupadi se retira e Bhima, coberto com o sangue de seu inimigo, dança celebrando sua vitoria. Após esta emblemática - e aterradora - vitória do bem sobre o mal, o deus Krishna volta ao palco, já sob as primeiras luzes da manhã, para uma dança de agradecimento ao público e aos deuses. 
O público se levanta lentamente, recolhe os pertences trazidos para ajudar a atravessar a noite - cobertores, almofadas, garrafas térmicas - e lentamente voltam para suas casas. É comum a ausência de aplausos ao final da apresentação, que é "recebida com uma espécie de aprovação silenciosa. $O$ ator desta tradição se coloca muito pouco à frente da obra à qual ele serve. Ele sabe que quanto mais ele se elimina, se aniquila, mais seu trabalho surge em toda a sua plenitude" (SALVINI, 1990, p. 21).

O odor de óleo de coco toma conta do local das indumentárias, no processo de remoção das tintas do rosto dos atores exaustos. Pouco tempo depois, a sala de maquiagem e vestimenta, está agora limpa de toda parafernália multicor. Após uma rápida oração, como último gesto da cerimônia espetacular, a pequena lâmpada a óleo, que investia de sacralidade e respeito o ambiente, é apagada.

Uma performance de Kathakali não é "apenas" uma performance teatral. É uma cerimônia na qual o ingrediente mais importante é, claramente, o componente dramático, mas nela tomam parte outros elementos: a dança, o ritual, a revisitação dos mitos e seus signos, a reafirmação dos valores religiosos, os ideais de honra guerreira e um singular fruir estético. Tudo isso amalgamando uma estética única no mundo, revestida de uma potente teatralidade, que recria sobre a cena uma dimensão que transborda a realidade. $\mathrm{E}$ faz do palco um território místico onde homens e deuses dialogam, em silêncio, como iguais e repisam passo a passo, gesto a gesto, noite após noite, a grande paixão dos seres humanos sobre a Terra e sua relação com tudo aquilo que os ultrapassa.

\section{O Teatro do Malabar}

O Kathakali representa a realização culminante, o produto final, da tradição secular de teatro indiano ao mundo. O caráter do Kathakali é heroico, majestoso, épico. Seu mundo é um mundo mágico, onde deuses e titãs materializam-se diante dos olhos para reviver e relevar suas fúrias e paixões elementares. O Kathakali proporciona, de maneira como nada mais o faz, uma crônica vibrante sobre o ethos e a psique de um povo que aprecia a arte como um de seus bens mais valiosos (KHOKAR, 1984, p. 96).

O Kathakali é um estilo masculino de Teatro-dança clássico originário na antiga região do Malabar, no extremo sudoeste da Índia. Sua forma final supõe-se ter sido atingida ao final do século XVII. Mas suas raízes culturais são encontradas em rituais dramatizados cujas primeiras documentações remontam a quase dois mil anos. Revitalizado nas primeiras décadas do século $X X$, reencontrou seu vigor com a criação, em 1920, no vilarejo de Cheruthuruthy, da primeira escola governamental para o ensino 
das artes, a Kerala Kalamandalam. A Kalamandalam é a principal escola de Kathakali do país e foi fundada por um dos mais famosos poetas do sul da Índia, Vallathol Narayana Menon, com o objetivo de resgatar as artes cênicas de Kerala. Kalamandalam significa "Academia de artes" e seu prestígio estabeleceu ao longo dos anos um padrão de excelência para todos os atores de Kathakali. A iniciativa de Vallathol se harmonizava com o espírito de resgate de valores nacionais patroneado por outro renomado poeta indiano, Rabindranath Tagore, prêmio Nobel de literatura em 1913, no bojo do movimento pela independência. A Índia se encontrava então sob o domínio inglês. Tagore morreu em 1941 e não pode testemunhar a vitória do movimento de libertação liderado por Mohandas Gandhi, a quem Tagore conheceu e alcunhou de Mahatma - a "grande alma"

Após a independência da Índia em 1947, o território do Malabar se reuniu às províncias de Cochin e Travancore, locais onde também se falava o malayalam, para formar o estado de Kerala, a "Terra dos cocos". Apesar da influência do marxismo materialista - em 1957, foi eleito ali democraticamente o primeiro governo marxista do mundo - a vida cotidiana em Kerala continuou intimamente associada ao culto de deuses. Kerala é a terra dos templos. Sua estreita área territorial abriga mais de dois mil templos em atividade e outros muitos inativos.

O Malabar foi durante séculos a terra das especiarias, do ouro negro, atraindo comerciantes de todo mundo: gregos, chineses, africanos e, mais tarde, portugueses, holandeses e ingleses. O intenso comércio com diferentes culturas, uma filosofia de convivência tolerante e sincretismo, a forte religiosidade e o gosto por grandes rituais religiosos, com a presença constante de elementos dramáticos, formaram os ingredientes necessários para o desenvolvimento do mais espetacular universo teatral da Índia.

Kathakali significa literalmente "representar historias". Em Kerala, outras tradições clássicas dividem espaço com ele, como o Mohiniattam - feminino - e o Krishnattam masculino, essencialmente religioso e atualmente restrito ao templo do deus Krishna, na cidade de Guruvayur. No templo de Guruvayur não é permitida a entrada de não hindus. Uma dança ritual com refinamento clássico e afastada do olhar do resto do mundo é realizada ali. Mas o Kutiyattam é considerado como a grande fonte estilística de onde todas as formas cênicas de Kerala se alimentaram. Surgido por volta do século VIII, o Kutiyattam foi declarado patrimônio universal da humanidade pela UNESCO. Os atores de Kutiyattam utilizam a voz para recitar os textos de sua dramaturgia, intei- 
ramente escrita em idioma sânscrito. O uso da voz foi abolido no Kathakali para dar espaço ao desenvolvimento das expressões faciais dos atores, que se tornou uma de suas características mais notáveis. Essa inovação expressiva, associada à utilização do malayalam em sua dramaturgia, além da familiaridade cultural dos espectadores com a mitologia hindu, fonte temática de todas as peças, tornou o Kathakali uma arte largamente popular, apesar de seu classicismo.

Além dessas, outras performances cerimoniais de caráter dramático convivem lado a lado em Kerala, como o Mutiyettu - ritual dramático que encena a lenda mitológica de Bhagavathi, deusa protetora de Kerala, o Ottan Thullal - dança semi-clássica e muito popular em Kerala, e o Teyyam - ritual de transe e de caráter oracular desprovido de caráter espetacular. Dentre todas, porém, se destaca o Kuttu, ou Chakkiar-Kuttu, pois é executado unicamente por membros da família dos Chakkiars. O Kutiyattam e o Chakkiar-Kuttu se misturam em suas origens e em suas próprias performances. O ator Kuttu participa por vezes da performance de Kutiyattam como uma espécie de narrador, servindo de ligação entre os espectadores e o que acontece em cena. Ele comenta, ironiza ou enfatiza momentos da cena. Nessa função ele é chamado Vidushaka e pode ora atuar na história, ora se abster da ação e se comunicar diretamente com a plateia, em um ancestral e intrigante jogo épico. O Kuttu representa o ponto-chave de transição entre o ritual puro e a formalização espetacular do Teatro de Kerala. Milena Salvini (1998) o define como o pai de todos os teatros de Kerala.

Em um curioso processo de desenvolvimento, etapas da evolução do teatro clássico de Kerala, ao contrário de se sobreporem e anularem as "etapas" anteriores, se justapõem formando um verdadeiro museu vivo do teatro, no qual se pode observar ainda hoje as diversas transformações e ramificações do desenvolvimento da arte teatral de Kerala. 


\section{Dançarino Guerreiro Sacerdote}

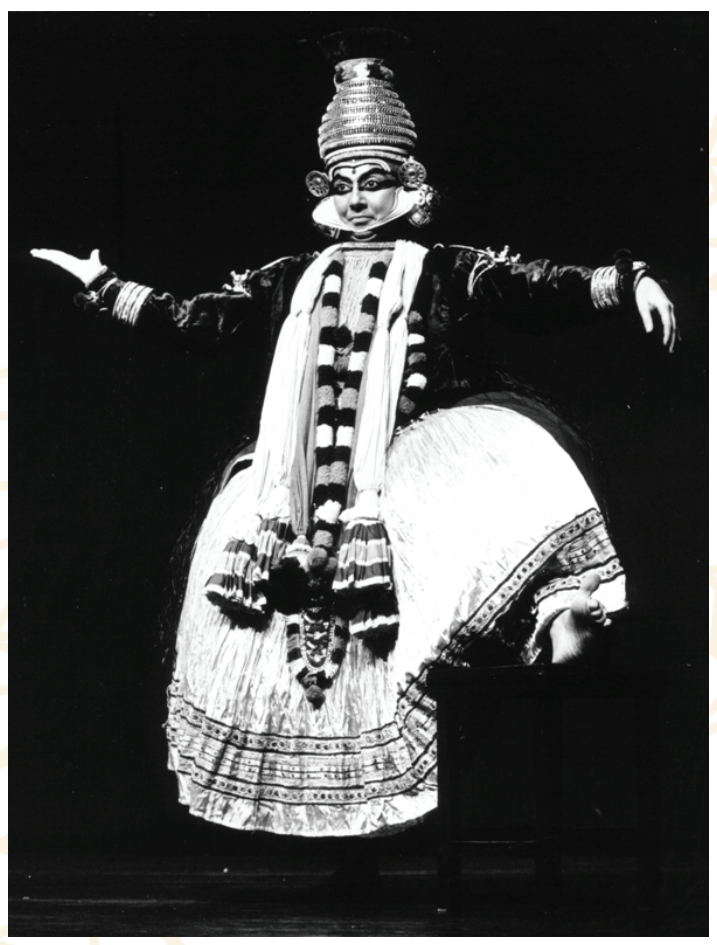

Na Índia acredita-se que todo palco seja um local sagrado escolhido pelos deuses, onde a eterna luta entre o bem e o mal deve se repetir para sempre. O Kathakali, sendo uma arte essencialmente hindu, é conduzido como um ritual e tudo que é relacionado a ele é investido de algum significado religioso. O ator em cena tem consciência do simbolismo da performance enquanto cerimônia propiciatória - normalmente em homenagem ao deus patrono do templo onde ocorre a performance - e da centralidade de sua atuação no contexto da oferenda. Sua aparição em cena, representativa de figuras mitológicas e divinas, encarna ideias e valores culturais que funcionam como eixos ao redor do qual orbitam as vidas da grande maioria da população da Índia e da audiência ali presente, em particular. Toda a cerimônia da performance possui uma sequência pré-definida e ritualizada que o ator deve respeitar e salvaguardar. Desde o momento em que chega à sala de maquiagem e vestimenta, e realiza sua primeira oração, até o momento em que vai embora, o ator age como um sacerdote a quem foi confiada a realização de uma oferenda cujo tesouro maior é exatamente sua atuação em cena. Um ator sacerdote.

Na tradição do Teatro clássico da Índia não existe uma diferenciação nítida entre teatro e dança. A palavra Natya engloba essas duas ideias de maneira amalgamada e indissociável. Todas as formas de teatro clássico da Índia possuem em sua estruturação 
cênica a dança, intrinsecamente entrelaçada aos elementos dramáticos. O que normalmente reconhecemos como "dança indiana" é, na verdade, teatro, também. Ou seja, Natya. De agora em diante, sempre que se mencionar a palavra "teatro" da Índia, entenda-se Natya. Nas formas clássicas de teatro da Índia, o ator é invariavelmente um dançarino.

A formação física destes atores dançarinos sacerdotes obedecia a uma antiga tradição de formação guerreira e marcial de Kerala, alimentada principalmente pela ancestral vocação comercial de Kerala. Povos das mais diversas partes do mundo aportavam à costa do antigo Malabar para negociar as valiosas especiarias, mas nem sempre com espírito pacífico. A defesa de suas terras, de seus tesouros e de seu comércio era de responsabilidade da casta dos guerreiros. Na tradição antiga, os meninos desta casta deveriam obrigatoriamente se submeter, desde tenra idade, a uma rígida preparação para as atividades militares, que remete ao sistema espartano de formação física e militar de infantes. "Kalaris eram ginásios para aulas de lutas onde os futuros guerreiros, provenientes principalmente da família dos Nayars, recebiam seu treinamento de combate físico. Esse sistema incluía uma rotina cuidadosamente planejada de exercícios e massagens, muito da qual foi adotada no Kathakali. De fato, o local onde o treinamento de Kathakali acontece ainda é chamado de Kalari" (KOKHAR, 1984, p. 38). Após alguns anos de um árduo treinamento físico, no qual o aprendizado da ancestral arte marcial de Kerala, o Kalarippayattu, era o ponto mais importante, um guru selecionava os mais habilidosos pupilos para uma outra função: o teatro. Um ator guerreiro.

\section{Construção do Ator}

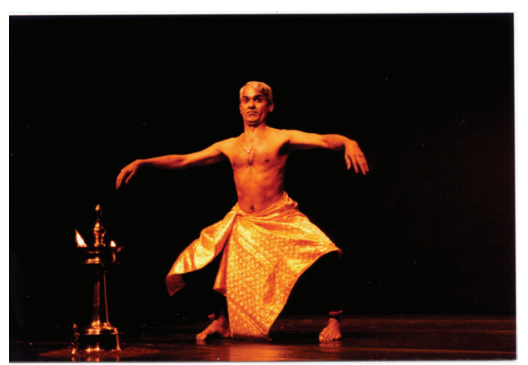

No Kathakali, mais do que um grande preparo físico, é necessária uma remodelagem da estrutura corporal do ator: muscular, motora, articular e psíquica. Para isso o Kathakali exige dedicação total e exclusiva dos pretendentes durante os anos de aprendizado. O Kathakali tem como ideia básica uma recomposição física do ator em cena, o que a aproxima de todas as outras formas clássicas cênicas - do Teatro 
Nô ao Ballet ocidental. Antinatural e definida de maneira minuciosa em todos os seus detalhes, a manutenção exata dessa composição será indispensável para a ativação energética necessária para a árdua performance. Essa remodelagem é observada de imediato em sua posição básica incomum e na maneira com que os atores se deslocam pelo palco. A recomposição física do corpo do ator ao longo de seu treinamento e a desumanização de sua figura em cena sedimentada ao longo dos séculos funciona como um alicerce sobre o qual toda a linguagem do Kathakali será elaborada. Podemos observar que, ainda que preze por suas tradições poética, musical, mitológica, dramatúrgica, o eixo central de toda elaboração artística do Kathakali é o ator.

\footnotetext{
Quando a cortina sobe, de fato, é tarde demais para começar um trabalho de arte. Exatamente como um texto de uma peça é o mesmo quem quer que seja o ator ou uma partitura de uma música não varia conforme quem a toque, também não há razão para que uma linguagem cênica deva variar com vista a tirar vantagem da personalidade do ator. É a ação, não o ator, o essencial para a arte dramática" (COOMARASWAMY, 1987, p. 3).
}

A rotina pedagógica ainda hoje mantém seu rigor militar. Para os alunos, essa rotina inicia antes do sol nascer, com massagens, exercícios físicos e exercícios para os olhos. Segue-se com um severo treinamento físico, coreográfico e gestual. E só se conclui à noite com a memorização dos textos dramatúrgicos e prática de ritmos (Talas) a serem utilizados nas partituras cênicas. Todos os alunos, ao final de seu aprendizado, devem obrigatoriamente ter aprendido todas as partituras (passos, gestos, Talas e expressões faciais) de todos os personagens de todas as peças do repertório tradicional do Kathakali. Pelo resto de suas vidas, esses atores dispensarão ensaios antes das apresentações. Durante a performance, independente de com esteja contracenando, o ator sabe exatamente o que o outro ator irá fazer, e em que momento. Como afirma Coomaraswamy: "Natya é uma arte deliberada. Nada é deixado ao acaso" (COOMARASWAMY, 1987, p. 3).

No Kathakali, a arte do ator e sua formação técnica atingiram uma complexa e refinada estruturação, na qual nada em cena é deixado ao acaso. Os atores ao entrar em cena seguem uma "partitura" previamente estabelecida, a partir da qual podem elaborar sua interpretação, e até mesmo improvisar dentro de certas molduras. Essa rígida padronização poderia fazer supor uma tradição repetitiva e desprovida de campo para a criatividade artística e subjetiva do ator. Mas não é o que ocorre. Assim como um pianista que interpreta uma partitura clássica, o ator identifica que essa moldura aparentemente rígida, ao contrário de ser uma prisão, liberta-o para elaborar com 
cada vez mais sensibilidade e subjetividade cada nota a ser tocada. Atuando como um intérprete dessa "partitura" extremamente elaborada, o ator atinge em seu trabalho altos níveis de detalhamento. Seus sutis refinamentos expressivos são admirados em suas minúcias e por causa de suas minúcias.

Exatamente como o texto de uma peça é o mesmo quem quer que seja o ator, exatamente como a partitura de uma música não varia conforme quem a tocará, também não há razão para que uma partitura cênica deva variar com vista a tirar vantagem da personalidade do ator. É a ação, não o ator, o essencial para a arte dramática" (Coomaraswamy, 1987, p. 3).

Um aspecto peculiar dentro desse sistema pedagógico severo e intensivo são as massagens às quais os alunos são submetidos diariamente por aproximadamente dois meses por ano, durante o período das monções. As massagens são realizadas de madrugada e são aplicadas pelos mestres de forma vigorosa com os pés. Com o auxílio de óleos com os quais untam o corpo dos alunos, o mestre vai aos poucos remodelando fisicamente o aprendiz. Com o forte e constante calor de Kerala, o ciclo de massagens aproveita o leve frescor da estação das monções para amenizar o superaquecimento da pele causado pela intensa fricção. O momento da massagem adquire uma gravidade ritual com a iluminação das lâmpadas a óleo, a untura dos corpos, o silêncio e a solenidade dos mestres. Os alunos se cobrem apenas com uma faixa de algodão amarrada fortemente na cintura e que lhes cobre a genitália. Antes do inicio da massagem e após saudações aos deuses a aos professores, uma sequência de exercícios corporais é necessária. Depois, deitados no chão, em posições específicas, recebem as enérgicas fricções dos pés dos mestres que lhes alongam a musculatura, tendões e articulações. Ao final de uma longa e penosa sequência de massagens, os alunos massageiam as pernas dos mestres em reconhecimento pelo esforço despendido em seu favor.

A relação entre mestre e aluno é um elemento peculiar da cultura indiana. $\mathrm{Na}$ Índia essa relação é conhecida como gurukulam (ou, aproximadamente, "sistema de gurus") ou gurushishya parampara (ou, aproximadamente, "tradição de gurus e aprendiz"). Neste sentido, a palavra guru contém um significado bem diferente da palavra professor. O papel do guru também possui maiores abrangência e profundidade, implicando uma relação com vários níveis e aspectos de ensinamentos. No aprendizado do Teatro de Kerala, o mestre que orientará a formação artística do ator será um mestre das técnicas da dança reconhecido por exemplar habilidade. Ele atuará e será respeitado como um guru "no sentido iogue" (SALVINI, 1990, p. 22). Esse mestre e guru é denominado áshan. 


\section{O Guru}

Normalmente os aprendizes de Kathakali iniciam seu aprendizado muito cedo, entre os oito e doze anos de idade, dentro de uma tradição familiar. O futuro aprendiz necessitará ser aceito por uma instituição ou, conforme o costume tradicional, por um áshan. Em ambos os casos, ele firmará um vínculo extremamente íntimo com o seu áshan que se perpetuará, na maioria das vezes, por toda a vida. No gurukulam original, o mestre antes de aceitar um aprendiz (shishya), recolhia o pequeno pretendente em sua casa pelo tempo que achasse necessário para avaliar sua disciplina, diligência e habilidades inatas. Se aceito, o aluno passaria a viver próximo ao áshan, de quem receberia toda a educação necessária para seu desenvolvimento. Esse rigor seletivo e didático se justifica pela crença profunda de que o shishya é um prolongamento, no tempo, de seu áshan. Uma vez terminado o aprendizado, o aluno se tornaria o "portador" do conhecimento de seu mestre. Por isso recebia o direito e a honra de adicionar o nome de seu professor ao seu próprio nome. Atualmente, aglutina-se o nome da instituição de ensino ou do local onde ela se situa. Por isso, os nomes como Kottakkal Nanda Kumaran (formado na escola de Kottakkal) ou Kalamandalam Udaya Kumar (formado pela escola Kalamandalam).

No sistema gurukulam, o processo de aprendizado é individualizado e, por isso, o tempo de estudo não podia nunca ser predeterminado: o mestre deveria decidir o momento em que julgasse haver completado o ensino de seu discípulo. Esse rigorosíssimo processo formativo de um ator poderia se prolongar por até vinte anos, ou mais. Atualmente, junto com a secularização do Estado indiano, o estudo das artes foi universalizado e padronizado. Assim como as escolas de ensino formal, os institutos de arte necessitam estipular uma programação para o ensino, uma matriz pedagógica com cronogramas especificados. Para os atores mais antigos, obviamente isso pareceu representar um enfraquecimento da tradição. O curso para a formação de atores na Kerala Kalamandalam foi estipulado em dez anos, o que, à luz da tradição, soava como um "intensivo". Apesar disso, o tempo demonstrou que a escola continuou formando atores de grande renome e excelência artística, como Kalamandalam Balasubramanian, Kalamandalam Udaya Kumar, Kalamandalam Keshava Namboodri e outros.

Recém-profissionalizados, ao final de seu tempo de estudo, os atores são considerados iniciantes e recebem poucos e pequenos papéis em suas primeiras performances. O padrão de qualidade do ator Kathakali é alcançado por volta dos quarenta 
ou cinquenta anos de idade, mas a pujança da arte é encontrada apenas nos velhos atores, que por isso são reverenciados por todos os outros atores, como verdadeiros áshans. Ao final do século XX, como representantes maiores em atividade dos últimos grandes áshans vivos, respeitados como bastiões dos valores mais caros ao Kathakali, colocam-se dois nomes de especial importância, que não podem deixar de serem citados: Kalamandalam Ramakutty Nair e Kalamandalam Padmanabhan Nair.

O sistema do gurukulam entrou em desuso nas artes, mas ainda pode ser esporadicamente encontrado em algumas circunstâncias no modelo antigo ou mesclado com o novo sistema secular. Mesmo nas instituições oficias de ensino de Kathakali, os alunos permanecem, algumas vezes durante todo seu tempo de aprendizado, vinculados a um único áshan.

Apesar do enorme avanço tecnológico e científico da Índia nos últimos anos, a ideia do gurukulam povoa o universo temático educacional da Índia e surge muitas vezes em pesquisas e debates acadêmicos, dialogando com as novas possibilidades pedagógicas contemporâneas. A sobrevivência do gurukulam como tema dialogante com questões tecnológicas, por exemplo, comprova a inclinação indiana a este modelo educacional extremamente pessoal e irrepetível, um dia considerado como o modelo de ensino perfeito na Índia.

\begin{abstract}
A alma só consegue receber estímulos de uma outra alma, e de nada mais. Podemos estudar em livros por toda a nossa vida, podemos nos tornar muito intelectuais, mas no fim, veremos que não desenvolvemos nossa espiritualidade. Não é verdade que um alto nível de desenvolvimento intelectual sempre caminha lado a lado com um proporcional desenvolvimento do lado espiritual do homem. (...) Para agilizar o espírito, o estímulo precisa vir de uma outra alma. A pessoa de cuja alma esse estímulo vêm é chamada Guru - o mestre. E a pessoa para cuja alma o estímulo é transmitido é chamada Shishya - o aprendiz. (VIVEKANANDA, 1981, p. 99)
\end{abstract}

\title{
O Tratado sobre Teatro
}

Segundo o Natya Shastra, quando os textos sagrados dos Vedas - escritos em sânscrito - se tornaram um privilégio para uns poucos letrados, os deuses apelaram à Indra, o rei dos deuses, para que fosse criada uma maneira de divulgar os quatro livros védicos, de modo que pudessem ser vistos, ouvidos e compreendidos por todos, independentemente de cultura ou casta. Indra incumbiu ao sábio Bharata Muni de criar esse "Quinto Veda", que popularizasse os ensinamentos tradicionais. Bharata Muni, após meditar longamente, concebeu Natya como o quinto Veda. Para orientar sua execução adequada, Bharata Muni escreveu o Natya Shastra (ou "Tratado sobre Teatro"). Esse 
livro deveria ser uma espécie de "manual" para esse novo modo de divulgação dos vedas, uma forma espetacular e representativa, popular o bastante para ser compreendido por todos, na qual o texto se conjugasse com a ação e o movimento.

Escrito provavelmente entre os séculos II a.C. e I d.C., o Natya Shastra é provavelmente o mais antigo livro existente sobre as artes cênicas. Uma verdadeira enciclopédia teatral, ele especifica detalhadamente todos os aspectos que envolvem uma representação dramática, desde as cores adequadas para a maquiagem, passando pela formação técnica dos atores, tipos de movimentos de cada parte do corpo, até a maneira correta de construção dos teatros, em suas exatas proporções. As indicações ditadas pelo Natya Shastra regulam ainda hoje e de forma marcante, mais de dois mil anos depois de ser escrito, a prática de todas as formas dramáticas na Índia. O Natya Shastra define o Teatro e as artes de um modo geral, como responsáveis não só pela sobrevivência da tradição cultural, mas também pela divulgação e pelo aprofundamento de seus valores morais, éticos, sociais e religiosos.

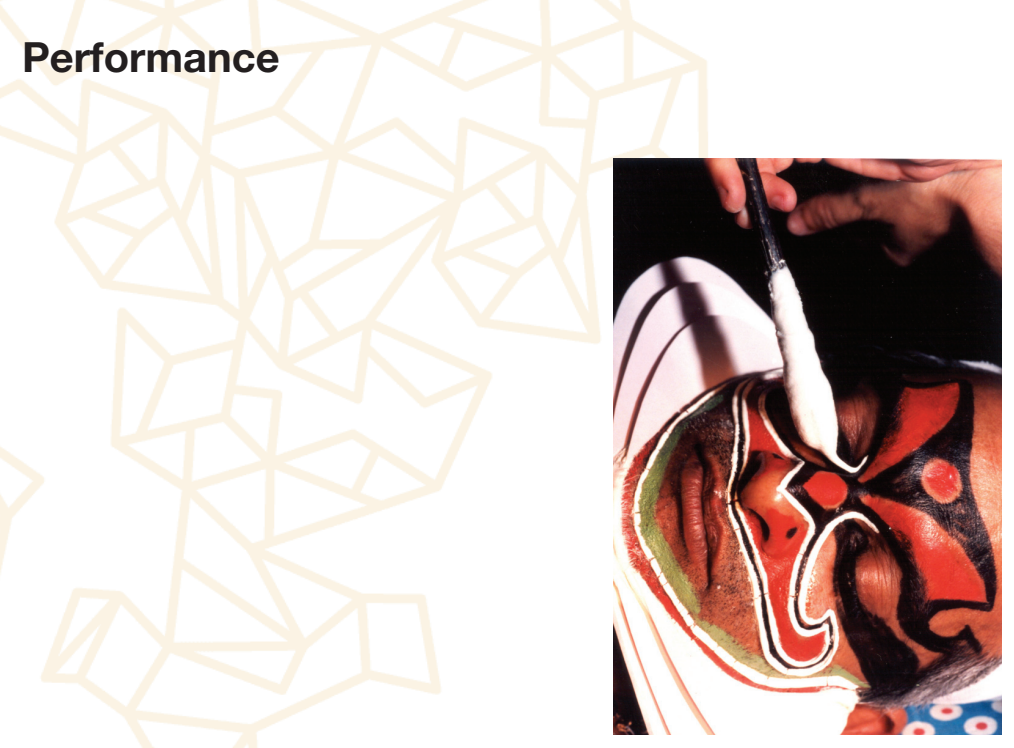

Quando se observa atentamente a tremendamente impressionante personificação de deuses, feita pelos dançarinos de Kathakali do sul da Índia, não há sequer um gesto natural a ser visto. Tudo é bizarro, tanto sub-humano e super humano. Os deuses-dançarinos não andam como pessoas, eles deslizam; eles não parecem pensar com suas cabeças, mas com suas mãos. Mesmo as faces humanas desaparecem atrás das máscaras esmaltadas. Nosso mundo não oferece nada que possa ser comparado a tal grotesca magnificência. Quando se assiste a um desses espetáculos, se é transportado ao mundo de sonhos, porque lá é o único lugar onde se pode conceber algo similar. Não há sombras ou semelhanças de uma realidade original, são mais como "realidades que ainda não foram". Realidades em potencial, as quais podem saltar o limiar da existência. (JUNG in SAVARESE, 1980, P. 31). 
Um espetáculo de Kathakali normalmente dura toda a noite e é iniciado por volta das seis horas da tarde, chegando ao fim apenas com a aurora do dia seguinte. Espetáculos de Kathakali geralmente são realizados como uma oferenda ao templo e sua divindade regente, e por isso obedecem a uma sequência ritual de etapas sagradas. As várias cerimônias que preparam a performance têm início pela manhã, bem antes do primeiro ator pisar o palco, com rituais no interior do templo e com músicos que percorrem os arredores anunciando o espetáculo que acontecerá à noite.

O palco do Kathakali é uma estrutura extremamente simples e rudimentar: uma pequena área elevada de chão batido, alguns poucos centímetros do nível do chão, coberta com uma lona rústica, e nada mais. Com a chegada do crepúsculo, uma grande lâmpada a óleo, que separa o palco da plateia, é acesa. Essa lâmpada possui dois pavios, o maior voltado para o palco e o menor para a plateia. Ela deverá ser obrigatoriamente acesa com a mesma chama que ilumina o altar da imagem do deus venerado no templo onde ocorre a performance. Se nos colocamos de frente para o palco, temos do lado direito ao fundo, dois cantores e na lateral esquerda, dois músicos e seus tambores, Tchenda e Maddalam, compondo a orquestra. Nenhum cenário ou outro recurso de iluminação é necessário.

A música do Kathakali observa os padrões da música clássica Karnatic, característica do sul da Índia, e distinta da música Hindustani, comum no norte do país. Dentre as modalidades de música Karnatic, o estilo marcadamente vocal e percussivo da música do Kathakali é reconhecido como o mais antigo e original representante da música clássica do sul. Os cantores cantam o texto dramatúrgico, que é representado em cena pelos atores. A música, como em todas as danças, serve de base para a contagem dos intérpretes em sua atuação. Mas na Índia não se utilizam números nessa contagem, mas sim sequências de fonemas, denominadas Talas. Existem inúmeros tipos de Talas, que podem formar longas frases, propiciando que possa existir não um, mas vários "tempos fortes." Além disso, eles podem variar de uma repetição da mesma frase para outra, oferecendo uma riqueza enorme de possibilidades e de complexidade. Um exemplo de Tala bem simples: Dhita Tata Tinda Tah Dhitei Tadhita Dikhtah Thei. Diz a lenda que a palavra Tala deriva da associação das duas principais qualidades da dinâmica do ator em cena: Ta se referindo à qualidade Tandava, masculina, relacionada à dança viril de Shiva. E La à qualidade Lasya, feminina, relacionada à suave dança de Párvati, esposa de Shiva. Além do Tala, há também diferentes tipos de 
ritmo (Ragas) que se adéquam à atmosfera e à emotividade da cena. A harmonização do Tala ao Raga é uma das tarefas internas e silenciosas do ator em cena.

O primeiro som a se ouvir sobre o palco deve ser a batida grave do Maddalam, simbolizando o grande som original, o primeiro som do Universo. Segundo a lenda, o deus Shiva criou o Universo batendo violentamente em seu tambor. Essa pequena introdução de música instrumental na qual os dois tambores da orquestra terminam tocando em dueto é denominada Keli e pode ser ouvida a grandes distâncias, avisando que o espetáculo está prestes a começar: "Em noites claras, o som do Tchenda viajava um quilometro desde o templo de Ayemenem, anunciando uma apresentação de Kathakali” (ROY, 1998, p. 196).

Após o Keli, terão início as performances. Uma cortina é trazida ao palco e, sustentada por dois homens à frente do palco, é estendida entre o palco e a plateia. Os atores adentram o palco encoberto pela cortina. De fato, a cortina parece servir mais para esconder o público do ator, do que o ator do público. Atrás da cortina, os atores fazem suas saudações a deus e aos instrumentos que tocarão durante sua performance. Se estiver em cena um ator mais velho, ele deverá também ser saudado com um toque em seus pés. "O tambor, a chama, as pessoas, tudo sugere inquietação. É parte do jogo, isto serve para criar e preencher a atmosfera para o que virá a seguir" (KHOKAR, 1984, p. 37).

Algumas danças propiciatórias antecedem as histórias propriamente ditas. A primeira delas chamada Todhayam tem duração de quase trinta minutos e é realizada inteiramente atrás da cortina, oculta do público. Uma dança especialmente dedicada aos deuses. Como define o Natya Shastra: "Os deuses nunca ficam tão agradecidos tendo sido reverenciados com incensos, essências e flores, como quando adorados com danças e dramas" (1989, p. 536). Uma segunda dança, Purappadu, serve para introduzir os principais heróis das histórias, geralmente o deus Krishna, seu irmão Balarama e suas consortes. O Purappadu no início do espetáculo tem um caráter simbólico, evocando a união entre Krishna e sua shakti, ou energia criadora, representada na forma feminina. No Hinduísmo, a união entre os sexos remete à busca humana de união com o divino. O Purappadu reelabora em cena a eterna comunhão dos contrários, que se complementam para gerar a tudo o que existe.

Nesse ponto começam as histórias, as peças propriamente ditas. Geralmente são apresentadas duas ou três peças por noite, cada uma tendo entre duas e três horas de duração. 
Retiradas dos grandes épicos, Mahabharata, Ramayana e Bhagavad Purana, as histórias revelam um universo povoado de deuses, super-homens, demônios e animais mitológicos. A programação da noite se encerra habitualmente com uma peça na qual, ao final, um demônio é morto de forma terrível, como a descrita na introdução deste trabalho.

Um recurso particular ao espetáculo de Kathakali e de grande efeito cênico é o Tiranokku ("aparição"), utilizado para introduzir um novo personagem. Neste momento, a cena é encoberta pela cortina. A audiência adivinha, através dos ruídos dos guizos, pisadas e rugidos, a presença misteriosa do novo personagem que dança atrás da cortina. Aos poucos, o ator abaixa a cortina revelando-se ao público. Este simples e eficaz artifício introduz a audiência à realidade fantástica do Kathakali e a conduz ao misterioso território habitado por seus personagens mitológicos.

O público, acomodado no chão, tem uma participação curiosa. Em certos momentos, os espectadores podem comer, levantar para tomar café, espreguiçar-se ou simplesmente deitar e dormir, sem que perturbem em nada os atores. É benéfico, acredita-se, simplesmente estar presente em uma performance de Kathakali. Não é um problema sair antes do final da performance ou chegar após seu início. O público conhece muito bem todas as histórias. As peças retiradas dos grandes épicos não proporcionam surpresas. Sua revisitação tem o sabor de uma cerimônia religiosa à qual se comparece periodicamente para reencontrar os mitos, as outras pessoas com as quais se compartilha os valores desses mitos e a si próprio.

Não importava que a história já tivesse começado, porque o Kathakali descobriu há muito que o segredo das grandes histórias é que elas não têm segredos. As grandes histórias são aquelas que você ouviu e quer ouvir de novo. Aquelas em que você pode entrar por qualquer parte e habitar confortavelmente. Elas não enganam com truques e finais emocionantes. Elas não surpreendem você com o imprevisível. Elas são tão familiares como a casa em que se vive. Ou como o cheiro da pele do amante. Você sabe como elas terminam, mas, mesmo assim, você escuta como se não soubesse. Da mesma forma que apesar de saber que um dia vai morrer, você vive como se não fosse. Nas grandes historias você sabe quem vive, quem morre, quem encontra o amor, quem não encontra. E, mesmo assim, quer ouvir de novo. Esse é o seu mistério e a sua magia. (ROY, 1998, p. 232) 


\section{O Sabor do Teatro}
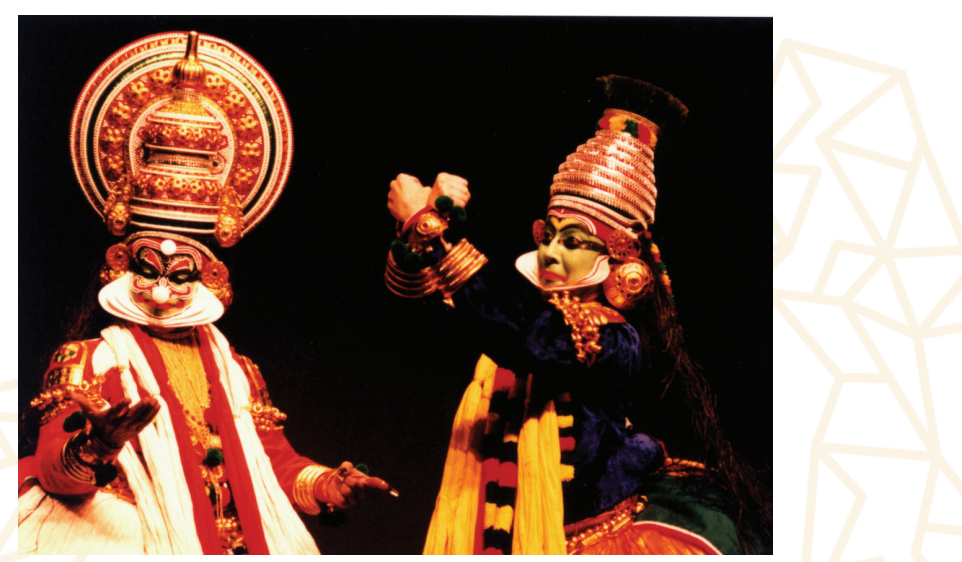

Ao contrário de outros estilos de teatros clássicos da Índia, como Bharata Natya, Kathak, Mohiniattam e Orissi, cujas performances são realizadas por um único intérprete, no Kathakali vários atores atuam ao mesmo tempo em cena. Cada ator interpreta um único personagem, ao contrário dos estilos solos, nos quais aquele que atua é um narrador que passa de um personagem a outro, sempre retornando ao narrador, fio condutor de toda história. No Kathakali não existe um narrador e o ator representa um único personagem e contracena com outros atores, podendo reagir a eles. Os atores atuam, portanto, conscientes da ideia de elaboração subjetiva de um personagem, o que propicia um aprofundamento das possibilidades e nuances de sua interpretação. O jogo entre ator e personagem é um outro aspecto revelador da vocação predominantemente teatral do Kathakali.

Todo o jogo do ator em cena sublinha a afirmação da teatralidade presente na linguagem do Kathakali. $O$ ator deve não só interpretar o texto, mas introduzir a plateia na atmosfera da história e reconstruir com seus próprios movimentos e gestos o ambiente em que se desenrola a ação. Ele reage aos outros atores em cena e à circunstância que ele mesmo cria com seu texto, o que faz com que ele assuma um duplo papel: o ator ao mesmo tempo em que constrói a vida subjetiva do personagem, também deve criar a circunstância em que esse personagem se encontra, e como ele reage a essa circunstância. Por exemplo, ele pode descrever a floresta em que o personagem está adentrando, para em seguida demonstrar como foi sua reação ao adentrar essa floresta. Numa outra possibilidade, o ator pode se "ausentar" enquanto outro ator atua e utilizar esse tempo para, à vista de todos, rearrumar seu figurino ou maquiagem. Ao contrário de representar uma quebra no jogo entre os atores, esse recurso termina por acentuar a teatralidade singular da linguagem cênica do Kathakali. 
Sendo a estilização o alicerce de toda a estruturação do teatro da Índia, a naturalidade, como é encarada no Ocidente, nunca foi um ingrediente cabível à equação teatral indiana. A arte cênica da Índia há muitos séculos reconhece que a "vida" em cena é necessariamente oposta àquela fora do palco. Para as ações da vida cotidiana, o Natya Shastra deu o nome de Lokadharmi - Loka (povo) dharmi (comportamento) - e para a ação artística, Natyadharmi - Natya ("Teatro") dharmi (comportamento). O "natural" pleiteado pelo elemento Lokadharmi não deveria pertencer, a princípio, segundo o Natya Shastra, ao universo artístico cênico. Como trabalha fundamentalmente com a consciência de que se encontra em um momento teatral, portanto artificialmente construída, o ator que busca estar "natural" em cena instaura um absurdo. Por isso, a "artificialidade" é um princípio básico no Teatro clássico indiano. O Natya Shastra define que "se ao invés de caminhar de maneira usual o personagem dança ou se movimenta com movimentos graciosos de membros e passos, isto é um exemplo de Natyadharmi" (1981, p.204). E mais adiante determina que "uma performance teatral deve invariavelmente utilizar Natyadharmi, pois a não utilização de gestos etc pelos atores estabelece estranheza aos espectadores" (1981, p. 204).

Estamos diante de um teatro que está o mais afastado possível do realismo
ocidental, um teatro incontestavelmente sagrado, que tem por ambição nos
transportar a um outro mundo, o dos deuses e dos heróis. O intérprete deve
esquecer-se de si em função do personagem que encarna. Trata-se de um
teatro transcendental, que descortina o além para aqueles que aceitam olhá-
lo, e que ao menos compreendem alguns rudimentos do código. Esse código
existe porque os deuses não podem apresentar-se a nós sob uma aparência
comum, usando linguagem banal. Eles não nos oferecem um espelho, mas
nos atraem em direção a um outro lugar, em direção aos territórios do mito e
da epopeia. A essência e a forma são inseparáveis (CARRIĖRE, 2002, p. 213).

Para "dizer" seu texto, o ator utiliza, como vimos, não a voz, mas um código gestual (Mudras) com vinte e quatro posições de mãos (Hastas), combinadas com movimentos de face e de tronco, que podem representar todas as palavras e expressões existentes. Ao conjunto desses elementos gestuais, faciais e corporais, bem como à utilização expressiva dos elementos utilizados em cena pelo ator, dá-se o nome de Abhinaya, palavra normalmente traduzida como "expressividade." Iyer define Abhinaya como "um termo abrangente, que cobre todos os aspectos da técnica dramática: atuação, gestos, música e ator, sua maquiagem e a expressão de estados psíquicos. Em um sentido muito mais estreito, no qual é comumente utilizado, denota o atuar/ dançar ou a mímica" (1987, p. 35). 
O ator Kathakali tem em seu rosto o seu principal meio expressivo. Através de um longo e rígido treinamento muscular da face, estes atores são capazes de um altíssimo grau de expressividade facial, "esculpindo" com extrema precisão, nuances mínimas em seu próprio rosto através de um absoluto controle dos músculos da face. $\mathrm{O}$ ator Kathakali, dispensado do uso da voz, tem disponível toda a musculatura do rosto para a composição de "máscaras" precisas e de grande riqueza de nuances. Ele é submetido desde a infância a um treinamento que busca controlar cada músculo do rosto, e ultrapassar os estereótipos mímicos. Os olhos recebem atenção especial, com um arsenal de exercícios específicos para seu controle, feitas no início da rotina diária de treinamento dos alunos. Um trabalho exclusivamente muscular, auxiliado pela aplicação de um tipo especial de manteiga sobre a superfície do globo ocular, buscando primeiramente desvincular a atividade muscular dos olhos, da ação de "ver". O resultado é a espantosa abertura, controle e expressividade conseguida pelos atores com seus olhos.

Existem nove expressões faciais básicas definidas pelo Natya Shastra. A execução adequada de cada expressão requer um difícil controle de pequenos músculos do rosto. Esse elenco de nove expressões faciais é chamado "Nava (nove) rasa (sabores)". A palavra rasa, traduzida literalmente, quer dizer sabor, ou deleite. Significa o prazer estético despertado no espectador pela interpretação do ator. Segundo o Natya Shastra, a arte do ator deve ser apreciada pela habilidade com que ele delineia o rasa (experiência do espectador) através de sua Abhinaya (expressividade do ator). E a pessoa capaz do bom gosto de apreciar e se deleitar apropriadamente com "os sabores" artísticos são conhecidos como Rasikas. As nove expressões faciais ou Nava Rasa são, com suas traduções aproximadas: 1. Sringaran (amor, quando em harmonia com a alegria); 2. Hassiam (desprezo irônico); 3. Karunan (tristeza ou compaixão); 4. Viran (heroísmo); 5. Roudra (Ira ou fúria); 6. Bhayanakam (medo); 7. Bibhetsan (asco ou qualidade terrível); 8. Adbhutan (encantamento) e 9. Shaandam (serenidade).

Bharata lyer define Rasa dissociando sentimento de emoção: "Amor é uma emoção, Sringaran é um sentimento (Rasa). As emoções que existem nos atores se desenvolvem em sentimento no espectador. O sentimento é diferente das emoções normais, ele é genérico e desinteressado, enquanto a emoção é individual e imediatamente pessoal" (1983, p.83). 


\section{Deuses e marionetes}

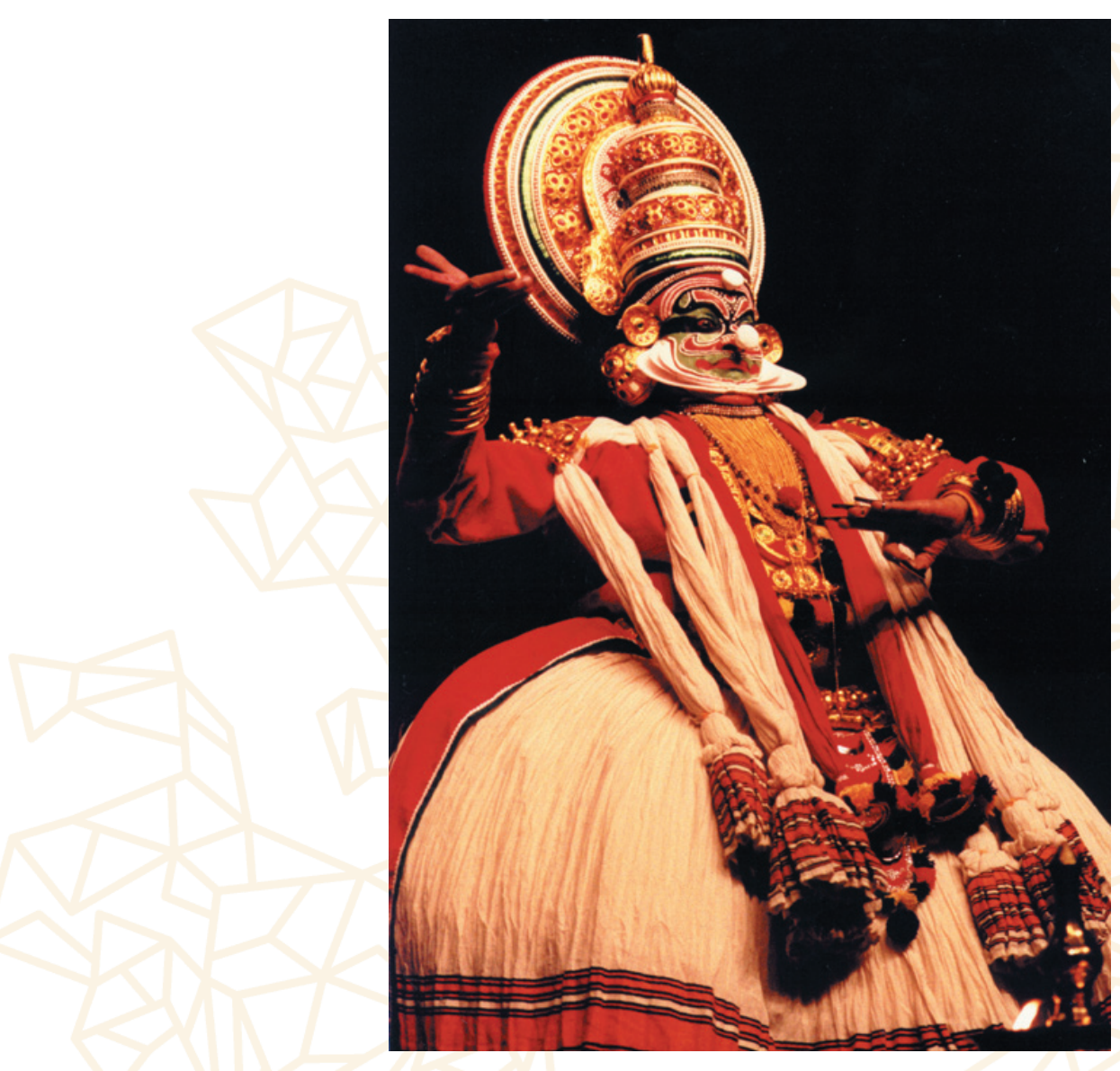

Mais ainda que a beleza dos espetáculos, era a minha incapacidade de compreender que me surpreendia. Por que, como espectador europeu eu ficava enfeitiçado por aqueles atores cuja história representada ou o sentido dela não conseguia entender nem a língua ou as convenções da recitação? O que é que me fazia seguir cada gesto, passo, dança, ou diálogo de surdo-mudo desses atores? Era a técnica deles que me deixava imobilizado durante uma noite inteira, sentado no meio de um público que caía de sono ou se levantava em continuação para espreguiçar as pernas, comer ou beber? Essas perguntas foram a verdadeira influência do Kathakali sobre mim. Durante anos e anos continuaram vivas, e depois reapareceram em outros contextos, guiando-me para uma tentativa de resposta que eu chamei de Antropologia teatral (BARBA, 2006, p. 74).

O elevadíssimo grau de refinamento de sua performance e sua obediência aos cânones estéticos definidos pelo Natya Shastra permite definir o Kathakali como uma arte clássica. O Kathakali com sua bizarra artificialidade acompanha, como já dito, a intuição asiática de que a linguagem da cena é, naturalmente, artificial. A separação entre a subjetividade do ator e o que ele formaliza em cena é explícita, e ali reside grande parte de seu encanto e potência expressiva. $\mathrm{O}$ apagamento da figura humana em cena oferece a possibilidade de uma formação atoral desprendida de um reconhecimento individual. Supostamente protegido de vaidades, o ator pode fazer aflorar 
apenas a arte e não o ego. E não por acaso, o Kathakali conseguiu elaborar, ao longo de seus trezentos anos de idade, um refinamento técnico incomparável, em todas as instâncias de sua performance. No entanto, completamente apagados e incógnitos por detrás de suas faces esmaltadas os atores e sua arte são, paradoxalmente, o coração do Teatro Kathakali, seu foco principal, o objetivo estético último, e a eles, seus atores, o Kathakali dedica todas as suas severas elaborações e benesses.

\begin{abstract}
Assumindo, logicamente, a diversidade das capacidades naturais, parece de forma natural existir menor diferença entre o bom e o mau ator, do que estamos acostumados observar na Europa moderna, porque o ator que meramente exibe a si mesmo é eliminado completamente. A diferença, ainda assim, existe, e um expert indiano é tão sensível a cada nuance quanto um crítico ocidental à vasta escala de variações no palco europeu. $\mathrm{O}$ ator perfeito possui o mesmo calmo e completo controle dos gestos que um atormanipulador possui sobre os movimentos de seus bonecos; a exibição de sua arte is completamente independente de suas condições emocionais, e se ele é movido pelo que ele representa, ele é movido como espectador, e não como um ator. (Coomaraswamy, 1987, p.4)
\end{abstract}

No Kathakali, os personagens são divididos em "tipos". Poderíamos utilizar a palavra "máscara", na tentativa de evocar, aproximadamente, a maneira como essa definição era compreendida na Commedia dell'arte. Cada "tipo" possui um figurino e uma maquiagem específicos, que indicam as principais características de comportamento e caráter sob os quais diversos personagens podem aparecer. Portanto, vários personagens aparecem sob o mesmo "tipo", com a mesma maquiagem e indumentária. Cada "tipo" possui uma qualidade particular de movimentos e gestos. Os principais "tipos" são, com a tradução aproximada do nome:

1. Patchá ("Verde") - A cor verde predomina na maior parte do rosto, indicando qualidades positivas. Com o rosto verde surgem, por exemplo, o deus Krishna e os cinco irmãos, Pandavas, heróis do Mahabharata. 2. Kattí ("Faca") - A cor verde se alterna com traços em vermelho, representando os personagens heróicos que apresentam ao mesmo tempo aspectos negativos. Essa maquiagem recebe este nome por possuir um bigode vermelho em forma de faca. Costumam emitir esporádicos sons roucos com a voz. 3. Chouvanna Taddi ("Barba vermelha") - A cor vermelha domina a maquiagem deste "tipo", indicando sua total negatividade, com características perversas e maléficas. Carregam uma larga barba vermelha estilizada abaixo do queixo e emitem altos urros durante sua atuação. 4. Vella Taddi ("Barba branca") Hanuman, o deus-macaco, devoto de Rama no épico do Ramayana. Tons de vermelho e preto se misturam em seu rosto, junto com a barba branca. A ponta de seu nariz é verde, demonstrando sua tendência ao bem. 5. Karuta Taddi ("Barba negra") - Perso- 
nagens selvagens e aborígenes, suas faces são completamente negras. Não são positivos nem negativos, pois não podem ser definidos conforme estes parâmetros, podendo agir das duas maneiras sem agravo para sua personalidade. Possuem uma flor branca na ponta do nariz, uma coroa de longas penas de pavão se abrindo para o alto e emitem sons agudos. Existe também um subtipo, Kari, especialmente para personagens femininos repulsivos, como demonessas. Seu aspecto bizarro é realçado pela presença de grotescos seios postiços. 6. Minukku ("Radiante") - Personagens femininos e de aparência humanizada, estilizando suavemente as linhas e cores naturais do rosto. Também designa a maquiagem dos personagens brâmanes, onde apenas uma barba postiça se soma ao reforço dos traços humanos.

A maquiagem para o Kathakali está entre as mais complexas do mundo. Como acabamos de ver, as cores no rosto do ator não são uma simples decoração, elas informam ao público as principais características dos personagens. Feitas de pós e pedras especiais macerados e misturados em óleo ou água, as tintas são preparadas muito antes do início do processo de maquiagem. Amarelo, azul, vermelho, branco e preto são as cores básicas. A partir delas todas as outras são criadas através de misturas em proporções exatas. As cores devem ser colocadas no rosto a partir de pontos específicos e sutis da anatomia facial de cada ator.

O elemento mais peculiar na maquiagem do Kathakali é o Tchutti, a pequena escultura de papel que contorna a face do ator, dando-Ihe imponência e fazendo com que as expressões pareçam saltar do rosto. Este papel é fixado por sucessivas camadas de pasta de arroz, que secam uma após outra, num trabalho artesanal, paciente e delicado, que pode levar até duas horas para sua confecção e colagem. Ao final da performance, ele é descartado. Existem profissionais especialmente treinados para esta etapa da maquiagem. O ator deve se deitar no chão para que o artista maquiador esculpa o Tchutti em seu rosto. Uma vez pronto, o Tchutti exigirá do ator um extremo cuidado, por sua enorme fragilidade.

A maquiagem se completa com a cor vermelha dos olhos, conseguida com a tintura desprendida pela semente de uma flor específica que é colocada delicadamente dentro das pálpebras. Inofensivo aos olhos, mas de grande impacto visual, o efeito desse tingimento desaparece completamente após quatro ou cinco horas.

Associado à imponente indumentária, a maquiagem faz parte do esforço do Kathakali em desumanizar a figura do ator. O majestoso figurino do Kathakali é 
composto por dezenas de peças de madeira, couro e pano, de diferentes tamanhos, cores e texturas. Muitos de seus detalhes são quase imperceptíveis ao espectador comum. A elaboração do figurino obedece ao ideal estético indiano, no qual o belo é composto de uma furiosa profusão de cores e formas. O Kathakali requer do espectador uma apreciação calma e desapressada de todos os seus aspectos. Essa demanda temporal do observador é uma característica de toda a arte tradicional indiana. O amor pelo detalhe parece concretizar a intuição estética indiana de uma contínua e dinâmica renovação na apreciação da obra de arte que esse detalhamento propõe. Essa estética feérica presente nas artes tradicionais indianas e, com particular esplendor na indumentária do ator Kathakali, traduz o próprio caleidoscópio cultural que é a Índia.

A parte mais impressionante do figurino do Kathakali é a Kirida, a majestosa coroa dourada ostentada por alguns personagens, toda ela entalhada em madeira maciça. Marca registrada da visualidade do Kathakali, sua imponência é um ponto central na desconfiguração da silhueta humana do ator em cena. Peça de maior importância de sua indumentária, o momento de colocá-la sobre a cabeça recebe uma atenção especial. O ator a retém em suas duas mãos e, de olhos fechados durantes alguns segundos, faz uma oração. Entre os incontáveis detalhes da Kirida podem ser encontrados trabalhos em prata, pedras semipreciosas e outros detalhes esculpidos com talos das penas de pavão.

Outro aspecto marcante do figurino é a portentosa saia que durante a dança parece ondular ao sabor do mar da Arábia que banha a costa de Kerala, como gostam de definir seus atores. Sob o belo pano pregueado, se escondem de 40 a 50 pedaços de algodão extremamente engomados, dobrados e amarrados fortemente à cintura do ator que fazem a saia expandir em uma bela circunferência ao redor do ator. Longas unhas de prata são anexadas às pontas dos dedos da mão esquerda. Uma tala com grandes guizos é atada às pernas e vão compor também sonoramente o espetáculo. O peso total do figurino de Kathakali pode chegar a quinze quilos.

O Kathakali atinge com sucesso o objetivo de desumanizar completamente a figura humana em cena. Na silhueta do ator em cena não se encontra nenhum traço de humanidade, destruindo completamente qualquer pretensão mimética e assumindo uma teatralidade grotesca e sublime. Em cena, são como enormes, magníficos bonecos regidos por uma mão invisível. E se movem e agem como marionetes superdotados. Essa marionetização do ator nos leva inevitavelmente a Gordon Craig e sua utopia sobre 
a Über-marionette, na qual ele reivindica a abolição do ator em cena: "O ator deve desaparecer e em seu lugar surgir a figura inanimada, a Über-marionette, podemos chamá-la assim, até que tenha conquistado para si um nome melhor" (2009, p. 34). No fundo, Craig clamava por um ator, liberto dos ventos do ego, e detentor das técnicas e habilidades referentes a seu ofício: "E é isso o que quero que os atores façam, alguns atores, os maus atores, quando eu digo que eles precisam se afastar e que a Über-marionette os substitua. (...) A Über-marionette é o ator mais fogo, menos egoísmo: o fogo dos deuses e dos demônios, sem a fumaça e o vapor da mortalidade" (2009, p. XXII).

Nicola Savarese (1992) pleiteia que Craig retirou sua inspiração para a criação de sua alegoria sobre a Über-marionette a partir de suas leituras sobre o teatro tradicional da Índia e desenvolveu a partir daí uma relação muito singular com o universo da arte indiana. Apesar de idealizá-las, não recomendava as tentativas de reproduzi-la: "Assim como não existe retorno para um verdadeiro amor, apesar de todas as dores, ainda que sejam aquelas do inferno, assim também não existe retorno da Índia" (Craig in SAVARESE, 1992, p. 404). Craig teria se encantado com a possibilidade de que o teatro da Índia tivesse surgido a partir do teatro de marionetes: "A Ásia foi seu primeiro reino. Às margens do Ganges eles construíram sua casa" (CRAIG, 2009, p.43). O termo "sutradhara, nome sânscrito que designa o diretor de teatro, significa literalmente 'aquele que puxa os fios' e indicava, exatamente por isso, também o manipulador de marionete, aquele que faz agir através de fios" (SAVARESE, 1992, p.390). A relação de ascendência do teatro de marionetes sobre o teatro tradicional é uma possibilidade que assume grande viabilidade ao se observar as silhuetas dos atores Kathakali em cena. O Abhinaya Darpana (ou, aproximadamente, "Espelho da gestualidade") é um antigo tratado sobre a gestualidade no teatro clássico da Índia. Em um capítulo da tradução feita por Ananda Coomaraswamy em 1917, uma nota explica o item que descreve as qualidades da dançarina em cena: "A atriz não deve estar suscetível a seus impulsos, mas possuir um perfeito autocontrole, senhora de uma arte estudada, de acordo com o ditado 'Como se manipulasse os fios de uma marionete"' (COOMARASWAMY, 1987, p. 16).

\section{Interculturalismo e o difícil diálogo entre mundos}

No melhor dos mundos possíveis, o interculturalismo pode ser visto como uma "via de mão dupla" baseado em uma reciprocidade de necessidades. Mas, na verdade, onde é o Ocidente, que estende sua dominação em questões culturais, esta "via de mão dupla" pode ser descrita com mais exatidão como um "beco sem saída" (BHARUCHA, 2005, p.2). 
Minha primeira experiência com o Kathakali, na Índia, se deu em 1989, com uma estadia de seis meses de treinamento intensivo e árduo, no mesmo vilarejo de Cheruthuruthy, onde Barba esteve observando o Kathakali, na década de 60. Seguiu-se a esta uma outra estadia de pouco mais de um ano de treinamentos e pesquisas, e é a partir desse contato bastante íntimo e do natural encanto com essa arte que essa pequena e incipiente descrição do Kathakali foi pensada.

Na década de 1960, alguns estudiosos (David Bolland, Philip Zarrilli, Milena Salvini e outros) pesquisaram o Kathakali e produziram alguns relatos importantes, mas foi com as experiências de Eugenio Barba e Jerzy Grotowski, nesta mesma época, que essa arte recebeu dimensão e notoriedade mundial. Antes disso, o teatro Kathakali era um universo praticamente desconhecido pelo Ocidente. A publicação em 1965 de um artigo de Barba com o relato de sua viagem à Índia dois anos antes e das três semanas que observou o Kathakali, e mais tarde, a publicação em 1968 de Em busca de um teatro pobre de Grotowski, no qual as experiências com as técnicas do Kathakali são descritas, serviram de introdução para o Ocidente aos meandros do universo do teatro clássico da Índia.

Em 1967, aconteceu a primeira apresentação de Kathakali em solo europeu, no evento Théâtre dês Nations, então sob a coordenação de Jean-Louis Barrault. Na década de 1970, Phillip Zarrilli faz sua primeira viagem à Índia especialmente dedicada ao estudo do Kathakali. Como resultado de uma extensa pesquisa, Zarrilli produz uma minuciosa descrição do Kathakali em um grande compêndio, The Kathakali Simples (1984) que, junto a A arte secreta do ator (1983), de Eugenio Barba, colocam pela primeira vez à disposição de pesquisadores fora da Índia um material abrangente e aprofundado sobre o assunto. Ou seja, o estudo do Kathakali e de suas possibilidades de diálogo com o teatro do Ocidente é relativamente recente.

O exotismo exuberante da formalização do Teatro Kathakali inspirou várias pesquisas e obras cênicas nas quais elementos de sua potente visualidade e expressividade eram "combinados" com a linguagem ocidental. Essa mescla, por vezes indiscriminada, de elementos culturais de distintas origens para criar um produto cênico, revelou-se muito bem aceita por crítica e público ocidentais. Baseado sobre parâmetros teatrais ocidentais, o "intercâmbio" com os teatros orientais ganhou ares de estilo estético e fundamentação teórica com terminologias como interculturalismo, internacionalismo etc. Este intercâmbio não apenas com o Kathakali, mas com outros estilos 
de formas de teatro-dança clássicos e semi-clássicos da Índia, bem como de outras partes do Oriente, foram - e ainda são - objetos de muitos debates e criticas. Um dos polos dessa polemica é determinar minimamente onde termina a pesquisa dialética entre estilos linguísticos distintos e onde começa a mera e indiscriminada apropriação de elementos exóticos e visual ou sonoramente atraentes.

Nós não temos nada a ganhar, como pretendem alguns, através da imitação pura e simples desta ou daquela antiga forma de teatro, de suas máscaras, de seus símbolos, de suas convenções, de seus costumes; é sobretudo pesquisando o espírito do qual estas formas exteriores e estes acessórios são expressões que nós podemos esperar encontrar alguma coisa de válido, aconselhável ou encorajador, que possa nos ajudar a dar forma às máscaras, aos símbolos e às leis de nosso teatro futuro (CRAIG in SAVARESE, 1992, p. 388).

Apesar da experiência que eu tinha com o teatro oriental, principalmente com o Kathakali indiano, não o utilizei como referência direta. Tentei fazer com que meus atores imaginassem esse teatro de cores e de exotismo, de acrobacias e religiosidade, apelando para a subjetividade e a imaginação de cada um. O Kathakali, como todo teatro oriental, não pode ser copiado, transplantado. Pode apenas servir de estímulo, de ponto de partida. (BARBA, 2010, p. 89)

Eu acho que deveria ser reconhecido que as implicações do interculturalismo são muito diferentes para as pessoas em países empobrecidos, 'em desenvolvimento', como a Índia, e para seus compartes de tecnologia avançada, sociedades capitalistas como os Estados Unidos, onde o interculturalismo tem sido fortemente estimulado tanto enquanto filosofia quanto forma de negócio (BHARUCHA, 2005, p. 1).

O diálogo entre a cena oriental e a ocidental ganhou intensidade e profundidade ao longo do século XX e esse universo dialético foi visitado por muitos pensadores do teatro ocidental: Gordon Craig, Vsévolod Meyerhold, Antonin Artaud, Bertolt Brecht, Richard Schechner, Rustom Bharucha e outros. Sobre esse delicado confronto, esses pensadores deixaram escritas suas intuições sobre suas ricas possibilidades, inspirações, mas também as possíveis idiossincrasias decorrentes dessa visitação.

\section{Um Krishna em neon azul}

Assim como não existe retorno para um verdadeiro amor, apesar de todas as dores, ainda que sejam aquelas do inferno, assim também não existe retorno da Îndia (Craig in SAVARESE, 1992, p. 404).

Por outro lado, o Kathakali também possui em sua dinâmica cultural procedimentos os quais permitem que sua performance sofra uma questionável "redução" para fins comerciais, em seu próprio local de origem. Alguns hotéis direcionados para turistas estrangeiros localizados em cidades do roteiro turístico de Kerala, como Cochin e Thiruvananthapuram (a capital do estado), oferecem pequenas apresentações de Kathakali como entretenimento para seus hóspedes. "À noite os turistas eram 
brindados com apresentações de Kathakali truncadas. (...) Clássicos de seis horas de duração eram retalhados em vinte minutos de melhores momentos. As apresentações aconteciam à beira da piscina. Enquanto os tocadores de tambor tocavam e os dançarinos dançavam, os hóspedes do hotel brincavam com seus filhos dentro da água" (ROY, 1998, p. 134). Essa prática é vista pela comunidade de atores como uma excrescência e aqueles que se sujeitam a essas apresentações são discriminados. Mas por vezes a realidade para alguns atores se torna tão dura quanto foi seu próprio treinamento físico. Tendo dedicado toda a vida para o Kathakali e não encontrando mercado de trabalho, alguns atores terminam se sujeitando a subempregos ou aceitando tomar parte nessas apresentações para turistas. Esse Kathakali dessacralizado, despido de suas propostas mais centrais e reduzido a um produto de entretenimento turístico, apresenta-se assim como uma alternativa para a sobrevivência de alguns atores.

O Kathakali enfrenta contemporaneamente alguns desafios a seu desenvolvimento e manutenção, naturais a esse tipo de tradição artística. É um surpreendente paradoxo como uma arte clássica, rigidamente elaborada como o Kathakali e que se utiliza de uma linguagem gestual hermética para comunicar seus textos, possa ser ao mesmo tempo (e ainda hoje) tão popular, principalmente nos pequenos vilarejos de Kerala. No entanto, no início desse século XXI, uma parcela de nova geração de indianos identifica esses aspectos culturais como representativos de uma Índia arcaica e atrasada para os padrões ocidentais, cada vez mais vigentes neste mundo globalizado. Zarrilli relata um encontro com um jovem, durante uma de suas viagens à Kerala. Ao perguntar se ele se interessava em Kathakali, junto a um sorriso irônico, ouviu: "Ah não, não tenho interesse algum por Kathakali. A maioria das pessoas da minha idade não tem interesse algum. A gente prefere ir ao cinema ou ver televisão" (ZARRILI, 2000, p. 8).

O Kathakali merece e necessita ser conhecido e compreendido como componente do que identificamos como Teatro contemporâneo, em toda a complexidade de tal definição. E sua tradição secular, assim como tantas outras ancestrais, dialoga com todas as outras cenas do mundo, ensinando e aprendendo. $\mathrm{O}$ amor pelo detalhamento e a riqueza de seu refinamento estético e linguístico é algo a ser admirado por aqueles que amam a arte. A tradição de seus atores, com seu treinamento e práxis, constitui um intrigante modelo de abordagem sobre a arte atoral. O Kathakali é o produto final de uma lenta elaboração cultural extremamente particular: única e irrepetível. Sua sobrevivência 
é um tesouro da humanidade. Colocado no século XXI, como está, vivo e dinâmico, levanta algumas questões importantes. Sobre o teatro e sobre a forma de pesquisar e fazer teatro, em qualquer parte do mundo. O Teatro Kathakali é uma das mais complexas e surpreendentes estruturações teatrais já realizadas na história do teatro e merece ser visitado. Longe de idealizar e criar padrões utópicos, esta pequena introdução almeja apenas apontar o convite a algumas reflexões que o Kathakali propõe, simplesmente através de sua estruturação. Que aquele que se aproxime deste universo, inspire-se de antemão em sua delicadeza, qualidade tão rara em nossos dias.

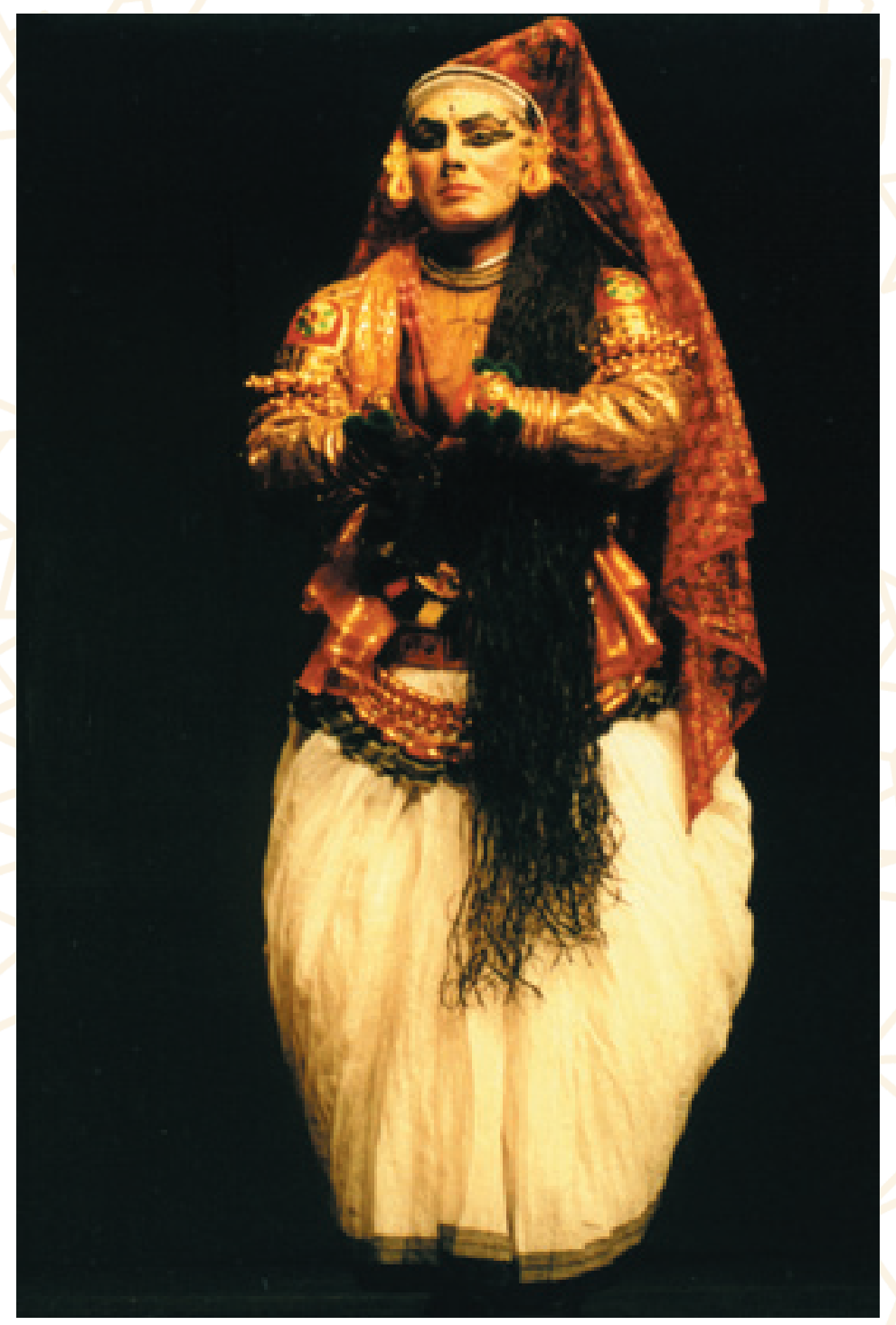

\section{Bibliografia}

BARBA, Eugenio. A terra de cinzas e diamantes. São Paulo: Ed. Perspectiva, 2006.

BHARUCHA, Rustom. Theatre and the World: performance and the politics of culture. Londres: Routledge, 2005 
CARRIÈRE, Jean-Claude. Índia, um olhar amoroso. Rio de Janeiro: Ediouro, 2002.

COOMARASWAMY, Ananda. The Mirror of gesture. Nova Delhi: Munshiram Manoharlal publishers, 1987.

CRAIG, Edward Gordon. On the Art of the Theatre. Londres: Routledge, 2009.

IYER, K. Bharatha. Kathakali. Nova Delhi: Oriental books Reprint Cop, 1983.

KHOKAR, Mohan. Traditions of Indian classical dances. Nova Delhi: Clarion Books, 1984.

RIBEIRO, Almir. Kathakali, uma introdução ao teatro e ao sagrado da Índia. Rio de Janeiro: Markprint, 1999.

ROY, Arundhati. O Deus das pequenas coisas. São Paulo: Ed. Schwarcz, 1998.

SALVINI, Milena. L'histoire fabuleuse du théâtre Kathakali à travers le Ramayana. Paris: Ed. Jacqueline Renard, 1990.

SAVARESE, Nicola. II Teatro al di là del Mare. Lodi: Studio forma editrice, 1980.

Teatro e Spettacolo fra Oriente e Occidente. Roma: editori Laterza, 1992

THE NATYA SASTRA of Bharatamuni. Nova Delhi: 1989, Sri Satguru Publications.

VIVEKANANDA, Swamy. The Teachings of Vivekananda. Calcutá: Advaita Asharama, 1981.

Zarrilli, Philip. The Kathakali complex. Nova Delhi: Abhinav publications, 1984.

Kathakali dance-drama.Londres: ed Routdlege, 2000. 